\title{
Leadership and Motivation in Public Quality Service: Case Study in the District Government Karimun Riau Islands Province Indonesia
}

\author{
Abdullah \\ University of Satyagama Jakarta, Indonesia
}

Received: March 29, 2016 Accepted: May 4, 2016 Published: March 5, 2016

doi: 10.5296/jsss.v3i2.9230 URL: http://dx.doi.org/10.5296/jsss.v3i2.9230

\begin{abstract}
This research was initiated by the rise of the business licensing service quality issues on the Government of Karimun Regency of Riau Islands province that has not been effective. The problem is detected, allegedly associated with the ineffectiveness of the leadership role, motivation, coordination and organizational commitment in the Government of Karimun Regency of Riau Islands province. The design of this study was conducted using a quantitative approach through explanatory survey method. Data analysis technique used is multiple linear regression. The study found that the role of leadership, motivation, coordination and organizational commitment either partially or simultaneously have a significant influence on the quality of the business licensing services to the Government of Karimun Regency of Riau Islands province. The results also reveal that motivation is the most dominant variable in affecting the quality of service business permit, then followed by a variable leadership role. This implies that the improvement of the quality of service the business licensing is determined by the implementing agency work motivation factor and the magnitude of the leadership role in supporting the success of the process of business licensing services.
\end{abstract}

Keywords: Leadership, Motivation, Public service

\section{Introduction}

Since the passing of the reform process dipenghujung 1998, the governance system has undergone significant paradigm shift. It is characterized by a shift in government management is centralized tends initially and then turned into a system of government based on democratic. The condition was later implicated in governance at the macro level, which requires changes in various sectors of national life. Juridical changes on governance in the region through the issuance of Law No. 32 of 2004 is a proof of change of government 
management is fundamental. This change brings the logical consequence of the need for institutional arrangements, especially in local government, both related to the structure, culture, personnel resources, authority, technology, including budget management system.

Urgency arrangement above the regional government institutions, inspired by the spirit of decentralization that emphasizes the principles of governance based on public services and social welfare. This is understandable given the public service is still in the spotlight and very serious attention from various circles, politicians, academics, and society at large. The strengthening of the public spotlight, and it underscored how far the public service remains a crucial problem that has not been able to be solved systematically and comprehensively by the government, both central and local government. The crucial issue, based on the growing phenomenon which reflects the poor quality of public services provided by the apparatus.

Service process cumbersome, inefficient, slow, unfriendly and the lack of service turnaround time is a concrete example of how poorly portrait of the services provided by the government apparatus. Such conditions also indicate that in carrying out the public service is not an easy job, because operationally always be faced with a very complex problem, and the challenges and obstacles even the "temptation" is not light.

In fact, the nature of public service as described in the minister's decision No. 63 of 2004 was "providing excellent service to the community which embodies the obligation of government officials as servants of the state and society". In other words, the true essence of public service regarding efforts to provide good services of government to the people as a manifestation of the obligations of government officials in performing their duties and obligations .. That's why then Zethaml and Farmer in Pasolong (2007: 133) warns that to understand the essence of service public there are three main characteristics that should be known, namely: first, Intangibility, means that the service is essentially a performance from the experience and not the object. Most services can not be counted, measured, felt, or testing before submission to ensure quality. In contrast to the goods produced by a factory that can be tested for quality before being delivered to customers. Second, Heterogenity, means service users or clients or customers have needs that are very heterogeneous. Customers with the same service may have different priorities. Similarly, performance often varies from one procedure to another procedure even from time to time. Third, Inseparability, means that the production and consumption of a service are inseparable. Consequently in industry quality services is not engineered into the production sector of the factory and then delivered to the customer. Quality occurred during the interaction between clients and service providers.

Therefore, it should be understood that the true essence of public service is not only limited to carrying out procedures and regulations based on the law or other regulations, but also should consider the output produced and the benefits perceived by those who served, the people. That is, whether the service provided has met expectations and public satisfaction? Even public officials, is actually able to present a product that not only provide services to the satisfaction of the public, but must also give the impression (impressive) to the public. That's why then Ratminto and Winarsih (2010: 58) distinguishes public service into two perspectives, namely "first, perspective or the providers of the process and the second, from the perspective of customers or output". Both perspectives that should be a reference to both parties (read: the officials and the community) in carrying out public services. 
Blurred portrait of public services as described above, in the same breath with a view Mahmudi (2007: 134) which says that “... in general, governmental organizations often face three problems that include less effective, in-efficient and quality service is lacking. Culture oriented towards achieving the target is one of the characteristics of bureaucratic organization." Unfortunately, the various phenomena associated with poor public services as in described above, not only hit the government at the central level, but also has been implicated in governance at the local level, as happened in the Government of Karimun Regency of Riau Islands province. As a district that has a strategic position, Karimun regency government still faces a number of issues of public services, especially regarding business licensing service area.

The results of a preliminary survey detected that the quality of licensing services, especially business licenses granted by the authorities in the Government of Karimun Regency in general is still relatively low. Problems are detected, it can be seen from the following indications: first, the persistence of the complaints submitted by the public related to the licensing service efforts made by government officials in the Government of Karimun. Based on the results of Government Performance Reports Karimun regency in 2013, obtained a description that public complaints related to licensing issues still relatively significant effort, which is about $9.2 \%$. This reflects that the licensing service enterprises within the Government of Karimun Regency has not been fully effective. So the implications for investment and business growth in Karimun.

\section{Research Methodology}

This research was conducted using a quantitative approach. Judging from the level of research, this study is the verification for testing the hypothesis. Then based on its shape, is placed on research that is causality (causality). The causal link in question is the poor quality of business licensing services due to the lack of effectiveness in leadership roles, motivation, coordination and non-optimal organizational commitment in the Government of Karimun Regency of Riau Islands province.

In other words, this study aimed to investigate the relationship of causality (cause and effect) between the role of leadership, motivation, coordination and organizational commitment in affecting the quality of services in the environmental business licensing in the Government of Karimun Regency of Riau Islands province. While research method used is Explanatory Survey method. A strengthening of the electoral method is based on the view Singarimbun and Sofian Effendi (1995: 2) which asserts that "this method not only to explain or describe the empirical facts found in the field but also will explain the analysis of the influence of both partially and simultaneously among the variables that are the focus research". To facilitate the implementation of the study, the researchers then make a research design in the form of a model as follows: 


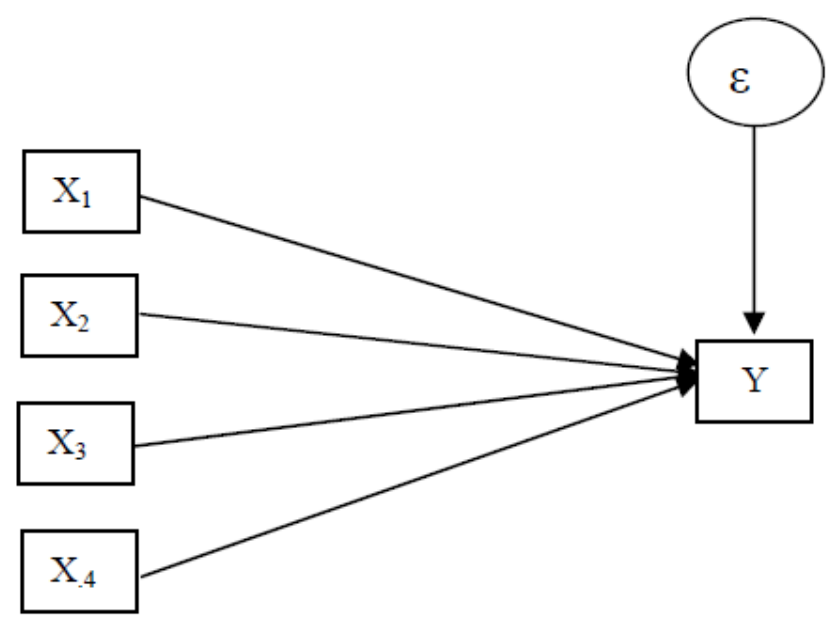

Figure 1. Relationship between variables

Information :

$\mathrm{X} 1$ = Leadership

$\mathrm{X} 2=$ Work Motivation

$\mathrm{X} 3=$ Coordinate

$\mathrm{X} 4$ = Organizational Commitment

$\mathrm{Y}=$ Quality of Service Sector Business Licensing

\subsection{Operational Variables}

According Singarimbun and Effendi, (1995: 67) "operational variables is important that researchers can connect abstract concepts into reality". Then through the operational variables before, researchers attempted to represent a phenomenon referred by the concept he uses. So operational research variables in this connection, is meant to describe and ease in setting measurement of the variables to be studied. Operational variables can also be used as a basis in making questionnaires, so as to assist in capturing the data as accurately as possible.

Operationally, the variables that have the opportunity to be elaborated in accordance with the objectives of this study may be many. Therefore, to further focus of research as well as to facilitate the process of identifying the variables of the study, the researchers will propose a conceptual definition as follows:

Essentially, conceptual term meant as a crystallization of some of the thoughts that then become new thinking through a study, analyzing results penelitian. Pelayanan business licensing is essentially an activity or activities undertaken by government officials, which in the context of this research is local government officials, namely apparatus Investment Board and Integrated Licensing, Environmental Agency, Department of Transportation, and Karimun District Mining Office is intended to meet the demands, needs and expectations of the community in accordance with the duties and functions in the context of governance and development. Thus, it is expected to improve the welfare of the community served.

The success of the business licensing services, is influenced by several factors, among others: 


\section{Mll Macrothink}

- The role of leadership

- Motivation

- Coordination

- Commitment to the organization

The role of leadership in question is an effort made by the Head of Investment and Integrated Licensing, Environmental Agency, Department of Transportation, and the Head of Mining oriented to building the capacity and skills of civil servants or officials in order to support the quality of service of business licensing. In this context, the role of leadership in driving the growth of the energy force of the subordinates, directed in achieving the objectives, guiding in taking risks, inspire and appreciate, so that officials / employees were able to perform their duties optimally.

Essentially, the leadership role will be running optimally, when the employee is motivation to work properly, either in the form of material and non-material. Motivation is encouragement or stimulus given by the leadership to employees so that they would perform Reviews their duties and tasks in accordance with the job that has set. Deskription the role of leadership and motivation will run optimally, when Awakened effective coordination Among the various stakeholders, both internal and external. Coordination is a synchronous and regular effort to provide the amount and timing as well as the direct implementation to produce a uniform and harmonious action on the targets.

The role of leadership, motivation and coordination will be running optimally and effectively, when backed by high organizational commitment of all components of the organization. Organizational commitment itself is a value orientation toward the organization that shows employees are extremely thinking and prioritizing the work and organization. Hanseker (2001:367) Leaders are concerned with bringing about change and motivating others to support that vision of change.

\section{Research result}

The study consists of four independent variables, namely; variable role of leadership, motivation, coordination, organizational commitment, and one dependent variable, quality of service licensing business field. As for the description of the study can be explained as follows:

\subsection{Leadership Roles}

Dimensions that measure variables is the leadership role of energy and determination, set goals, challenge and encourage, to take risks, to inspire and help employees feel valued. Each dimension consists of two (2) a statement, in which the results are tabulated in the table below: 
Table 1. Respondents answer recapitulation against variable leadership roles

\begin{tabular}{|c|c|c|c|c|c|c|c|c|}
\hline \multirow{2}{*}{ No } & \multirow{2}{*}{ Indicator } & \multicolumn{5}{|c|}{ \% Alternative answer } & \multirow{2}{*}{$\begin{array}{l}\text { Total } \\
\text { Score }\end{array}$} & \multirow{2}{*}{ Category } \\
\hline & & SA & A & $\mathbf{N}$ & D & SD & & \\
\hline 1 & $\begin{array}{l}\text { The leadership must encourage the growth of the power to } \\
\text { employees, so as to improve the quality of care licensing }\end{array}$ & 65.8 & 29.7 & 2.6 & 1.9 & 0.0 & 712 & $\begin{array}{l}\text { Very } \\
\text { Good }\end{array}$ \\
\hline 2 & $\begin{array}{l}\text { Leaders have the ability to build courage officials in } \\
\text { supporting the process of licensing services }\end{array}$ & 19.4 & 74.2 & 5.2 & 1.3 & 0.0 & 638 & Good \\
\hline 3 & $\begin{array}{l}\text { Leaders have the ability to formulate the goals of the } \\
\text { organization, particularly with respect to licensing services }\end{array}$ & 27.1 & 65.2 & 5.8 & 1.9 & 0.0 & 647 & Good \\
\hline 4 & $\begin{array}{l}\text { Leaders lack the ability to implement the goals of the } \\
\text { organization associated with the licensing service }\end{array}$ & 9.7 & 23.9 & 51.6 & 11.6 & 3.2 & 426 & $\begin{array}{l}\text { Pretty } \\
\text { Good }\end{array}$ \\
\hline 5 & $\begin{array}{l}\text { Leaders have the ability to control the organizational } \\
\text { challenges }\end{array}$ & 11.6 & 76.8 & 11.0 & 0.6 & 0.0 & 619 & Good \\
\hline 6 & $\begin{array}{l}\text { Leaders lack the ability to cope with the risk of the } \\
\text { organization, making it less supportive of the process of } \\
\text { licensing services }\end{array}$ & 0.6 & 9.0 & 11.0 & 65.2 & 14.2 & 594 & Good \\
\hline 7 & $\begin{array}{l}\text { Institutionally, the leadership has the readiness to take risks, } \\
\text { thus supporting the success of the licensing service }\end{array}$ & 55.5 & 32.9 & 9.7 & 1.9 & 0.0 & 685 & $\begin{array}{l}\text { Very } \\
\text { Good }\end{array}$ \\
\hline 8 & $\begin{array}{l}\text { In person, the leadership has a high initiative in developing } \\
\text { the organization, thus supporting the improvement of } \\
\text { quality of service licensing }\end{array}$ & 25.2 & 67.1 & 5.8 & 1.9 & 0.0 & 644 & Good \\
\hline 9 & $\begin{array}{l}\text { Psychologically, the leader has to have the ability to } \\
\text { understand the wishes of the employees in providing } \\
\text { licensing services }\end{array}$ & 0.6 & 3.9 & 8.4 & 32.9 & 54.2 & 254 & Not Good \\
\hline 10 & $\begin{array}{l}\text { Leaders lack the readiness to assist employees who have } \\
\text { difficulty in providing licensing services }\end{array}$ & 0.0 & 9.0 & 5.8 & 38.1 & 47.1 & 656 & $\begin{array}{l}\text { Very } \\
\text { Good }\end{array}$ \\
\hline & & & & & & & 7144 & Good \\
\hline
\end{tabular}

Source: Data Analysis Questionnaire, 2015.

The leadership role is empirically $77.7 \%$ have influence on the quality of the business licensing service area on the Government of Karimun Regency of Riau Islands province. This implies that the hypothesis which says a leadership role significant effect on the quality of services in the field of business licensing Karimun acceptable empirically.

\subsection{Work Motivation}

Dimensions that measure dimensions of work motivation is extrinsic and intrinsic dimension. Extrinsic dimension consists of five (5) statements and intrinsic dimension consists of 5 (five) statement. The results are tabulated as shown in the table below 4:12 this: 
Table 2. Respondents answer recapitulation against variable work motivation

\begin{tabular}{|c|c|c|c|c|c|c|c|c|}
\hline \multirow{2}{*}{ No } & \multirow{2}{*}{ Indicator } & \multicolumn{5}{|c|}{ \% Alternative answer } & \multirow{2}{*}{$\begin{array}{l}\text { Total } \\
\text { Score }\end{array}$} & \multirow{2}{*}{ Category } \\
\hline & & SA & $\mathbf{A}$ & $\mathbf{N}$ & D & SD & & \\
\hline 1 & $\begin{array}{l}\text { Wages received so far, has not been entirely feasible to meet } \\
\text { the needs of employees }\end{array}$ & 25.2 & 12.3 & 3.2 & 18.1 & 41.3 & 524 & $\begin{array}{l}\text { Pretty } \\
\text { Good }\end{array}$ \\
\hline 2 & $\begin{array}{l}\text { Security in implementing the licensing service, guaranteed } \\
\text { by agencies }\end{array}$ & 36.1 & 53.5 & 7.7 & 2.6 & 0.0 & 656 & $\begin{array}{l}\text { Very } \\
\text { Good } \\
\end{array}$ \\
\hline 3 & $\begin{array}{l}\text { Conduciveness working environment has not been fully } \\
\text { developed well, so it is less supportive of the process of } \\
\text { licensing services security in carrying out licensing } \\
\text { services, guaranteed by agencies }\end{array}$ & 0.6 & 11.6 & 65.2 & 12.3 & 10.3 & 496 & $\begin{array}{l}\text { Pretty } \\
\text { Good }\end{array}$ \\
\hline 4 & $\begin{array}{l}\text { Employment status of the employees had been assured by } \\
\text { both }\end{array}$ & 54.8 & 22.6 & 13.5 & 8.4 & 0.6 & 655 & $\begin{array}{l}\text { Very } \\
\text { Good }\end{array}$ \\
\hline 5 & $\begin{array}{l}\text { Institutionally, employees have ease in carrying out the } \\
\text { procedure of licensing services }\end{array}$ & 1.3 & 66.5 & 27.1 & 5.2 & 0.0 & 564 & Good \\
\hline 6 & $\begin{array}{l}\text { The quality of personal relationships between employees } \\
\text { are not yet fully developed well, so it is less supportive of } \\
\text { the process of licensing services }\end{array}$ & 0.0 & 7.1 & 56.8 & 26.5 & 9.7 & 525 & $\begin{array}{l}\text { Pretty } \\
\text { Good }\end{array}$ \\
\hline 7 & Institutionally, achievement highly valued employee & 52.3 & 32.9 & 6.5 & 7.7 & 0.6 & 664 & $\begin{array}{l}\text { Very } \\
\text { Good }\end{array}$ \\
\hline 8 & $\begin{array}{l}\text { The leadership must provide for recognition of the work } \\
\text { achieved servants }\end{array}$ & 54.2 & 31.6 & 9.0 & 5.2 & 0.0 & 674 & $\begin{array}{l}\text { Very } \\
\text { Good }\end{array}$ \\
\hline 9 & $\begin{array}{l}\text { The leadership must encourage employees to take } \\
\text { responsibility for the work that has been done }\end{array}$ & 40.0 & 49.0 & 3.2 & 5.8 & 1.9 & 650 & Good \\
\hline 10 & $\begin{array}{l}\text { All employees have an equal opportunity to develop } \\
\text { themselves }\end{array}$ & 24.5 & 63.2 & 11.0 & 0.0 & 1.3 & 635 & Good \\
\hline & & & & & & & 6647 & Good \\
\hline
\end{tabular}

Source: Data Analysis Questionnaire, 2015.

The results of data analysis has proven that empirical work motivation provide significant impact on the quality of services in the field of business licensing Karimun regency of $82.3 \%$. The magnitude of these findings indicate that the hypothesis which says work motivation significantly influence the quality of the field of business licensing services can be received empirically.

\subsection{Coordination}

Dimensions that measure variables is the sense of coopertaion coordination, rivalry, team spirit and esprit de corps of each dimension consists of 2 (two) statement, and the results are tabulated as follows: 


\section{Macrothink}

Table 3. Respondents answer recapitulation against variable coordination

\begin{tabular}{|c|c|c|c|c|c|c|c|c|}
\hline \multirow{2}{*}{ No } & \multirow{2}{*}{ Indicator } & \multicolumn{5}{|c|}{$\%$ Alternative answer } & \multirow{2}{*}{$\begin{array}{l}\text { Total } \\
\text { Score }\end{array}$} & \multirow{2}{*}{ Category } \\
\hline & & SA & A & $\mathbf{N}$ & D & SD & & \\
\hline 1 & $\begin{array}{l}\text { Employees are encouraged to have the ability to cooperate } \\
\text { associated with licensing service }\end{array}$ & 18.1 & 74.2 & 5.2 & 2.6 & 0.0 & 632 & Good \\
\hline 2 & $\begin{array}{l}\text { Willingness to provide assistance is not yet fully developed } \\
\text { well, so it is less supportive of the process of licensing } \\
\text { services }\end{array}$ & 3.9 & 65.8 & 21.3 & 8.4 & 0.6 & 564 & Good \\
\hline 3 & Leaders promoting the competition among employees & 27.1 & 58.1 & 11.6 & 3.2 & 0.0 & 634 & Good \\
\hline 4 & $\begin{array}{l}\text { Leaders have the ability to control competition among } \\
\text { employees }\end{array}$ & 49.0 & 27.1 & 18.1 & 5.2 & 0.6 & 649 & Good \\
\hline 5 & $\begin{array}{l}\text { Spirit of cooperation has developed well, thus supporting } \\
\text { the quality of service licensing }\end{array}$ & 15.5 & 60.6 & 19.4 & 3.9 & 0.6 & 599 & Good \\
\hline 6 & Mutual respect among fellow employees have been well & 12.3 & 39.4 & 41.3 & 5.8 & 1.3 & 551 & Good \\
\hline 7 & $\begin{array}{l}\text { Commitment to each other to maintain the good name is not } \\
\text { fully awakened well }\end{array}$ & 0.6 & 10.3 & 18.7 & 65.2 & 5.2 & 564 & Good \\
\hline 8 & $\begin{array}{l}\text { The level of employee participation in every process of } \\
\text { licensing service is still low }\end{array}$ & 4.5 & 18.1 & 66.5 & 9.0 & 1.9 & 487 & $\begin{array}{l}\text { Pretty } \\
\text { Good }\end{array}$ \\
\hline 9 & $\begin{array}{l}\text { Leaders lack the ability to implement the goals of the } \\
\text { organization associated with the licensing service }\end{array}$ & 9.7 & 23.9 & 51.6 & 11.6 & 3.2 & 426 & $\begin{array}{l}\text { Pretty } \\
\text { Good }\end{array}$ \\
\hline 10 & $\begin{array}{l}\text { Leaders have the ability to control the organizational } \\
\text { challenges }\end{array}$ & 11.6 & 76.8 & 11.0 & 0.6 & 0.0 & 619 & Good \\
\hline & & & & & & & 4680 & Good \\
\hline
\end{tabular}

Source: Data Analysis Questionnaire, 2015.

Coordination undertaken by stakeholders in the field of business licensing empirically Government of Karimun Regency has an impact of $79.9 \%$. These results implies that the hypothesis that reads coordination significant effect on the quality of services in the field of business licensing Karimun acceptable empirically.

\subsection{Organizational Commitment}

Dimensions that measure organizational commitment variable is emotionally, felt needs and desires, the cost / sacrifice, trust and loyalty. Then each of these dimensions, translated into 10 (ten) statement, and the results are tabulated as follows: 
Table 4. Respondents answer recapitulation against variable organizational commitment

\begin{tabular}{|c|c|c|c|c|c|c|c|c|}
\hline \multirow[b]{2}{*}{ No } & \multirow[b]{2}{*}{ Indicator } & \multicolumn{5}{|c|}{$\%$ Alternative answer } & \multirow{2}{*}{$\begin{array}{l}\text { Total } \\
\text { Score }\end{array}$} & \multirow[b]{2}{*}{ Category } \\
\hline & & $\begin{array}{l}\text { STRANGLY } \\
\text { AGREE }\end{array}$ & AGREE & NETRAL & DISAGREE & $\begin{array}{l}\text { VERY } \\
\text { DISAGREE }\end{array}$ & & \\
\hline 1 & $\begin{array}{l}\text { Sense of belonging to the } \\
\text { organization has not fully } \\
\text { grown among employees }\end{array}$ & 0.0 & 11.6 & 12.9 & 69.0 & 6.5 & 574 & Good \\
\hline 2 & $\begin{array}{l}\text { Still there are some employees } \\
\text { who do not yet fully have the } \\
\text { willingness to work optimally }\end{array}$ & 1.3 & 9.7 & 54.2 & 30.3 & 4.5 & 507 & Pretty \\
\hline 3 & $\begin{array}{l}\text { Leaders pay less attention to } \\
\text { the need to develop the } \\
\text { organization }\end{array}$ & 3.9 & 15.5 & 11.0 & 21.9 & 47.7 & 611 & Good \\
\hline 4 & $\begin{array}{l}\text { The desire to make } \\
\text { organizational changes } \\
\text { difficult to materialize, due to } \\
\text { a lack of support led }\end{array}$ & 2.6 & 14.2 & 9.7 & 63.9 & 9.7 & 564 & Good \\
\hline 5 & $\begin{array}{l}\text { Still there are some employees } \\
\text { who do not have the ability to } \\
\text { make sacrifices for the } \\
\text { organization }\end{array}$ & 2.6 & 21.3 & 23.9 & 47.1 & 5.2 & 513 & $\begin{array}{l}\text { Pretty } \\
\text { Good }\end{array}$ \\
\hline 6 & $\begin{array}{l}\text { Leadership has encouraged } \\
\text { employee loyalty to the } \\
\text { organization }\end{array}$ & 8.4 & 33.5 & 51.6 & 6.5 & 0.0 & 533 & Good \\
\hline 7 & $\begin{array}{l}\text { As an employee, I do not fully } \\
\text { believe in the organization }\end{array}$ & 2.6 & 14.8 & 11.6 & 23.2 & 47.7 & 618 & Good \\
\hline 8 & $\begin{array}{l}\text { Leaders are less able to build } \\
\text { confidence in the employees }\end{array}$ & 3.9 & 13.5 & 14.2 & 30.3 & 38.1 & 597 & Good \\
\hline 9 & $\begin{array}{l}\text { During this time the leader has } \\
\text { stressed the importance of } \\
\text { loyalty to the organization }\end{array}$ & 20.6 & 13.5 & 34.8 & 23.2 & 7.7 & 490 & $\begin{array}{l}\text { Pretty } \\
\text { Good }\end{array}$ \\
\hline 10 & $\begin{array}{l}\text { Leaders have not been fully } \\
\text { able to foster loyalty among } \\
\text { employees of the organization }\end{array}$ & 5.2 & 17.4 & 15.5 & 21.3 & 40.6 & 581 & Good \\
\hline & & & & & & & 5588 & Good \\
\hline
\end{tabular}

Source: Data Analysis Questionnaire, 2015.

The results of data processing illustrating that variable organizational commitment has an 
impact on service quality field of business licensing in Karimun regency of $4.7 \%$. These results prove that the hypothesis that reads organizational commitment significantly influence service quality field of business licensing in Karimun regency government acceptable empirically. Determined by the dimensions of organizational commitment emotionally, feel the need and desire, sacrifice, trust, loyalty dimensions.

\subsection{Quality of Service Business Licensing}

Dimensions that measure service quality variables are comvenience business licensing, security, realiability, person attention, problem solving approach, faireness fiscal, responsibility and citizen influence each of these dimensions consist of 10 (ten) statement, and the results are tabulated as follows

Table 5. Respondents answer recapitulation of variable quality business licensing services

\begin{tabular}{|c|c|c|c|c|c|c|c|c|}
\hline \multirow[b]{2}{*}{ No } & \multirow[b]{2}{*}{ Indicator } & \multicolumn{5}{|c|}{$\%$ Alternative answer } & \multirow{2}{*}{$\begin{array}{l}\text { Total } \\
\text { Score }\end{array}$} & \multirow[b]{2}{*}{ Category } \\
\hline & & $\begin{array}{l}\text { STRANGLY } \\
\text { AGREE }\end{array}$ & AGREE & NETRAL & DISAGREE & $\begin{array}{l}\text { VERY } \\
\text { DISAGREE }\end{array}$ & & \\
\hline 1 & $\begin{array}{l}\text { Institutionally Karimun } \\
\text { regency government has } \\
\text { sought to ease airport } \\
\text { licensing procedures }\end{array}$ & 58.7 & 31.0 & 9.7 & 0.0 & 0.6 & 693 & $\begin{array}{l}\text { Very } \\
\text { Good }\end{array}$ \\
\hline 2 & $\begin{array}{l}\text { An information campaign } \\
\text { licensing service has been } \\
\text { performed regularly }\end{array}$ & 49.0 & 38.7 & 11.0 & 1.3 & 0.0 & 675 & $\begin{array}{l}\text { Very } \\
\text { Good }\end{array}$ \\
\hline 3 & $\begin{array}{l}\text { Security in providing } \\
\text { licensing services is an } \\
\text { important concern for the } \\
\text { Government of Karimun } \\
\text { Regency }\end{array}$ & 56.8 & 34.8 & 6.5 & 1.3 & 0.6 & 691 & $\begin{array}{l}\text { Very } \\
\text { Good }\end{array}$ \\
\hline 4 & $\begin{array}{l}\text { Karimun District Government } \\
\text { encourages staff members to } \\
\text { provide licensing services are } \\
\text { right on target }\end{array}$ & 21.9 & 69.0 & 7.1 & 1.9 & 0.0 & 637 & Good \\
\hline 5 & $\begin{array}{llr}\text { Timeliness } & \text { in providing } \\
\text { licensing } & \text { services is } \\
\text { considered } & \text { by the } \\
\text { Government } & \text { of Karimun } \\
\text { Regency } & & \end{array}$ & 51.6 & 37.4 & 8.4 & 2.6 & 0.0 & 679 & $\begin{array}{l}\text { Very } \\
\text { Good }\end{array}$ \\
\hline 6 & $\begin{array}{l}\text { So far, the district government } \\
\text { has provided licensing } \\
\text { services according to the } \\
\text { needs of society }\end{array}$ & 51.0 & 31.6 & 12.3 & 3.9 & 1.3 & 662 & $\begin{array}{l}\text { Very } \\
\text { Good }\end{array}$ \\
\hline
\end{tabular}




\begin{tabular}{|c|c|c|c|c|c|c|c|c|}
\hline 7 & $\begin{array}{l}\text { Licensing services democratic } \\
\text { process has awakened in } \\
\text { Karimun regency government } \\
\text { environment }\end{array}$ & 7.1 & 76.8 & 13.5 & 1.3 & 1.3 & 600 & Good \\
\hline 8 & $\begin{array}{l}\text { Fairness in providing } \\
\text { licensing services } \\
\text { commitments } \text { for } \\
\text { Government } \text { of } \\
\text { Regency }\end{array}$ & 56.8 & 28.4 & 11.0 & 2.6 & 1.3 & 677 & $\begin{array}{l}\text { Very } \\
\text { Good }\end{array}$ \\
\hline 9 & $\begin{array}{l}\text { Karimun District Government } \\
\text { emphasizes the importance of } \\
\text { budget efficiency in serving } \\
\text { the licensing process }\end{array}$ & 19.4 & 57.4 & 20.6 & 1.3 & 1.3 & 608 & Good \\
\hline 10 & $\begin{array}{l}\text { The district government has } \\
\text { not fully pursue an } \\
\text { improvement in serving the } \\
\text { licensing process }\end{array}$ & 6.5 & 12.3 & 23.9 & 54.8 & 2.6 & 519 & $\begin{array}{l}\text { Pretty } \\
\text { Good }\end{array}$ \\
\hline & & & & & & & 10085 & Good \\
\hline
\end{tabular}

Source: Data Analysis Questionnaire, 2015.

3.6 Role of Leadership, Motivation Work, Coordination, and Organizational Commitment and Quality of Service Sector Business Licensing in Karimun regency of Riau Islands Province

Simultaneously (together) the role of leadership, motivation, coordination and commitment by empirical organization has a very significant influence on the quality of services in the field of business licensing Karimun Regency of Riau Islands province. The magnitude of the effect produced, namely $88 \%$. These results implies that the hypothesis which says the role of leadership, motivation, coordination and organizational commitment significantly influence the quality of the field of business licensing services can be received empirically. These results also imply that success in improving service quality field of business licensing in Karimun is determined by how much the role of leadership, motivation, coordination and commitment to the organization being run by the institution responsible for the management of field service business licensing, both within the Agency planting Capital and Integrated Licensing, Department of Transportation, the Department of Mines and Energy and the Environment Agency.

\section{Conclusions and Recommendations}

\subsection{Conclusion}

Based on the results of the study, researchers can deduce some of the following results:

1) There is a leadership role influence on the quality of public services in the field of business licensing Karimun Regency of Riau Islands province amounted to $77.7 \%$. This result implies that the improvement of the quality of public services areas of business 
licensing in Karimun, determined by success of leadership in growing a tough stance for employees, the ability of the leadership in formulating the organization's goals, the ability to control organizational challenges, encourages subordinates to be able to cope risks, the ability of the leadership in taking the initiative for the advancement of the organization to help employees in their duties.

2) There is the influence of motivation to work on the quality of public services in the field of business licensing Karimun Regency of Riau Islands province of $82.3 \%$. Results penenlitian it, implies that increasing the quality of public services areas of business licensing in Karimun, determined by factors as motivation, both extrinsic, such as the feasibility of income, security in carrying out the work conduciveness work environment, employee status, the ease of working procedures, and maintain the quality of personal relationships, and Motivating factors that are intrinsic like; success achievement, recognition of work, responsibility, advancement of employees and employees the possibility to develop his career.

3) There is a coordinating influence on the quality of public services in the field of business licensing Karimun Regency of Riau Islands province amounted to 79.9\%. This shows that the improvement of the quality of public service areas of business licensing in Karimun, determined by the ability to carry out co-operation, the ability of leaders to control competition among employees, growth of mutual respect among fellow officers, and awakening the spirit to carry out the task as well as the establishment of a commitment to look after each good name.

4) There is the influence of organizational commitment to quality public services in the field of business licensing Karimun Regency of Riau Islands province of 4.7\%. It shows that the success in improving the quality of public services areas of business licensing in Karimun Riau Islands Province, is determined by the strength of the attitude of a sense of belonging to the organization, the need to develop and carry out organizational changes, the ability of employees to make sacrifices for the organization, to build confidence in the employees, and the ability to cultivate loyalty among employees.

5) Put together a leadership role, motivation, coordination and organizational commitment affect the quality of public services in the field of business licensing Karimun Regency of Riau Islands province by $88 \%$. The results of this study showed that simultaneous or jointly Overall these variables have contributed very significantly and determine improving the quality of public services in the field of business licensing Karimun Regency of Riau Islands province. Of the four independent variables studied, it can be concluded that work motivation is the most dominant variable in influencing the quality of public services areas of the business licensing, which amounted Motivation $82.3 \%$, followed by $79.9 \%$ Coordination variable. This implies that improving the quality of public services, in particular licensing services is largely determined by factors of work motivation implementing agency and coordination in supporting the success of the public service.

\subsection{Suggestion}

Departing from the results of research and discussion, the comprehensively researchers can provide recommendations or suggestions as follows: 
1) It is necessary to optimize the role of leadership, both within the Investment Board and Integrated Licensing, Environmental Agency, Department of Transportation and Karimun District Mining Office, especially related to leadership roles in the context of supervision in order to support the effective implementation of the process of business licensing services. Thus, business licensing services given more responsive, adaptive and accountable, so as to ensure the continuity of the process of business licensing services in accordance with the rules and expectations of society.

2) It takes a stronger motivation, either in the form of material and non-material, so that the implementing agency is compelled to carry out the process of business licensing services more optimally. Thus, it is expected to grow the desire of the implementing agency to carry out their duties properly, in accordance with the vision and the mission carried by the organization. In addition, it is expected to grow their awareness and a paradigm shift in assessing the essence of public services, particularly those related to the licensing service efforts that the success of the process of licensing services business, actually not only be achieved through a process of service that are providers (under the terms) only, but also must consider the psychological factors that are needed by the community. One of the concrete steps that could be done through the concept of assistance to the implementing agency licenses accompanied by the provision of adequate incentives in order to encourage increased service performance resulting apparatus. In the end, the environmental services business licensing in Karimun can be viewed from two perspectives, namely the perspective of providers (rules) and customers (people served). Balance between the two perspectives is then expected to inspire the birth process licensing service quality.

3) There needs to be synergy and more intensive coordination and a sustainable among stakeholders in the management process of business licensing services, in both the Investment Board and Integrated Licensing, Environmental Agency, Department of Transportation, and the Department of Mines. The concrete steps that can be done to translate these recommendations, among others; First, the perception of policy implementation of business licensing services in Karimun regency government environment. Second, make joint evaluations continuously that essentially discuss the effectiveness of the process of business licensing services. Thus, it is expected to be dismissed their sectoral ego of each party in the process of handling the business licensing services.

4) There should be a systematic effort and firmly in order to provide reinforcement to increase the commitment of officials in performing their duties as a public servant. It is very important to do, given the licensing service is a very complex thing, so it requires seriousness, thoroughness and patience are adequate. In this context then, the commitment of the implementing agency is strongly needed. The concrete steps that can be done to translate on the stretcher, among others; create rules that are binding for all stakeholders in the process of licensing services can comply with agreed commitments. Thus, the process of licensing services that can be implemented effectively.

5) In order to increase the capacity and competence of personnel, there needs to be a comprehensive strategic move and that is manifested through the development of design policy packages that essentially related to program quality development personnel resources. As a concrete step in translating the development program the quality of personnel resources, 
including through provision of opportunity for all personnel to follow a training program in accordance with the demands and needs of the organization. Education and training programs intended meaning not just implement training programs besifat formality, but must be completely scalable and provide a real contribution towards improving the quality of personnel resources. Therefore, the implementation of the training given is also necessary in the evaluation and enhanced regularly, both in relation to the substance and implementation of the model of training itself. It was considered important to assess the success and effectiveness of the implementation of the training program.

\section{References}

Alma, B. (2007). Manajemen Pemasaran dan Pemasaran Jasa. Bandung: Alfabeta

Al-Rasyid, H. (1997). Teknik Penarikan Sampel dan Penyusunan Skala. Bandung, Pascasarjana-UNPAD

Mahmudi, (2007). Manajemen Kinerja Sektor Publik. Yogyakarta: UPP STIM YKPN

Mangkunegara, A. A., \& Anwar, P. (2000). Pola Prilaku Kepemimpinan Orientasi Prestasi Dalam Hubungannya Dengan Motivasi Berprestasi dan Penerapan Budaya Organisasi Pada Koperasi, Disertasi, Program Pascasarjana UNPAD.

Ndraha, T. (1999). Budaya Organisasi. Jakarta: Rineka Cipta

Ndraha, T. (2005). Kybernologi: Sebuah Rekonstruksi Ilmu Pemerintahan, Jakarta: PT. Rineka Cipta.

Pasolong, H. (2007). Teori Administrasi Publik. Bandung: Alfabeta

Pasolong, H. (2010). Kepemimpinan Birokrasi. Bandung: Alfabeta

Phillip, L. H. (2001). Training in Management Skills. Prentice Hall, New Yrok.

Prawirosentono, S. (1999). Manajemen Sumber Daya Manusia: Kebijakan Kinerja Karyawan, Kiat Menuju Organisasi Kompetitif Dalam Perdagangan Bebas Dunia, Yogyakarta: BPFE.

Rasyid, M. R. (1997). Makna Pemerintahan. Yasrif Watampone, Jakarta.

Ratminto, dan W., \& Septi, A. (2005). Manajemen Pelayanan: Pengembangan Model Konseptual, Penerapan, Citizen's Charter dan Stándar Pelayanan Minimal, Yogyakarta: Pustaka Pelajar.

Siagian, S. (1998). Organisasi Kepemimpinan dan Perilaku Administrasi, Jakarta, Gunung Ilmu.

Singarimbun, M., \& dan Sofian, E. (1995). Metode Penelitian Survei, Cetakan Ke II, Jakarta: LP3ES.

Soehartono, I. (2003). Analisis Jalur (Path Analisis), Bandung, Lemlit Unpas.

Soehartono, I. (2000). Metode Penelitian Sosial, Bandung: PT. Remaja Rosdakarya.

Stoner, J. A. F. (1996). Management, Third Edition. Prentice-Hall InternationalInc. Englewood. Clllips. New Jersey.

Sugandha, D. (1991). Koordinasi Alat Pemersatu Gerak Administrasi, Jakarta, Intermedia.

Sugiono. (1998). Metode Penelitian Administrasi, Bandung, Al-fabeta.

Tangkilisan, H., \& Nogi, S. (2005). Kebijakan Publik Yang Membumi, Yogyakarta: Yayasan 
Pembaharuan Administrasi Publik Indonesia \& Lukman Offset.

Tjiptono, F. (2006). Manajemen Jasa, Yogyakarta: ANDY OFFSET.

Tjiptono, F., \& dan Chandra, G. (2007). Service, Quality \& Satisfaction, Edisi 2, Yogyakarta: ANDY OFFSET.

Tjiptono, F. (2005). Prinsip-Prinsip Total Quality Service, Yogyakarta: ANDI OFFSET.

Tsui, A. S., \& Pearce, J. L., \& Porter, L. W. (1997). Alternative Approachesto the Employee-Organization Relantionship: Does Investment in Employee Pay Off. Academy of Management Journal, 40(5), 1089-1121. http://dx.doi.org/10.2307/256928

Udai, P. (1985). Motivational Analysis of Organizational Behavior MAO-B, University Associates, Inc.

Usman, H. (2000). Metodologi Penelitian Sosial, Jakarta: Bumi Aksara.

Wasistiono, S. (2002). Diktat Kuliah Metodologi Ilmu Pemerintahan, Program Pasca Sarjana MAPD STPDN, Jatinangor.

Yuk1, G. A. (1998). Leadership in Organizationals (4th ed). Prince Hall, Upper Saddle.

Zeithaml, V. A., Parasuraman, A., \& Barry, L. L. (1990). Delivering Quality of Service: Balancing Customer Perception and Expectation. New York: The Free Press.

\section{Copyright Disclaimer}

Copyright for this article is retained by the author(s), with first publication rights granted to the journal.

This is an open-access article distributed under the terms and conditions of the Creative Commons Attribution license (http://creativecommons.org/licenses/by/3.0/). 